\title{
The Role of Millennials in the Development of Creative Industries as a Poverty Reduction Effort in Bengkulu City
}

\author{
Veny Puspita*, Fauzan and Deni Triyanto
}

\author{
Department of Management and State Administration Science, Universitas Prof Dr. Hazairin SH, Bengkulu, Indonesia \\ *Corresponding author. Email: venypuspita2288@gmail.com
}

\begin{abstract}
In this paper, we propose a solution to reduce poverty in Bengkulu City through the role of the millennial generation in development of creative industry. This research uses a qualitative descriptive method that directly points to the potential of the millennial generation in developing creative industries. The data sources of this research consisted of secondary data and primary data. Secondary data were obtained from agencies or institutions, both formal and informal. While the primary data is obtained from Participatory Rural Appraisal (PRA) approach with observation data collection techniques, interviews, focus group discussions (FGD) and brainstorming. The results showed that the role of the millennial generation in developing creative industries such as product development, prices, places, promotions and resources has the potential to rapidly grow and develop as an effort to reduce poverty in Bengkulu City. This study is expected to become a reference for the government in overcoming poverty in Bengkulu City and making the creative industry a leading sector in Bengkulu City.
\end{abstract}

\section{Keywords: Millennial generation, Creative industry, Poverty}

\section{INTRODUCTION}

Poverty is understood as an economic phenomenon, which is referred to the situations in which an individual or families cannot achieve socially acceptable living income standards [1]. Poverty is a major problem hindering the development of the world's community that must be resolved immediately. The complex problem of poverty requires the intervention of all parties together and coordinated because the handling of $\mathrm{s}$ poverty problem today tends to be partial and unsustainable. The role of the business world and society in general is not optimal. Poverty is complex and must be resolved immediately because it concerns various aspects of life. Poverty can also involve a variety of other challenges outside the economy including deprivation, marginalization, discrimination, and poor health [2].

The problem in this study is that Bengkulu is one of the cities with the highest poverty rate in Indonesia. It ranked second in Sumatra Island with people's income still relying on agriculture, plantation, and marine products while the creative economy sector that is considered promising has not been the leading sector in Bengkulu city. Therefore, it has not been able to reduce the problem of poverty in Bengkulu City [3].

So far, poverty policy and alleviation has been widely carried out by the central government or local government, but the program has not been able to encourage people to be independence in Bengkulu City. To promote welfare levels in Bengkulu City, it is necessary to pass various policies such as the development of creative industry products through the role of millennial [4]-[5].

The role of human resources is an important factor in the formation of local creative in Bengkulu City. According to data from the Central Bureau of Statistics the number of millennials is $55 \%$ of the population in Bengkulu City, this means that this generation with the age of 40-19 years will be the backbone of the economy of the society [6]. Here the role of millennials is very important in reducing the poverty that occurs in the city of Bengkulu.

The existence of millennials, led to a change in the behavior of creative economy industry players. A generation that is independent, creative and has integrity with its creative efforts will be able to produce valuable creative products. The creative industry will be an event 
for millennials to express, creative industries are a large sector in the absorption of the workforce and able to give birth to creative ideas and be able to develop the idea in various creative economy efforts, especially in Bengkulu City [ 7]-[10].

Creative industry players must now race to think about how to develop creative products with up-to-date concepts and develop creative economic diversity to increase global competitiveness. The creative industry can be a supporting sector of the economy in Bengkulu city as well as reducing poverty.

In general, this research aims to provide solutions to decrease poverty rates in Bengkulu city through millennials role in the creative industries development. While the special purpose of this research is as an effort to find and mapping the creative economic area developed by millennials in Bengkulu City. The hope is that this document can be useful in the preparation of poverty alleviation strategies in Bengkulu City and make the creative industry as the leading sector in Bengkulu city through the role of millennials.

\section{METHODOLOGY}

This research uses qualitative descriptive methods that directly lead to the potential of millennials developing creative industries. Through this approach can be known and understood the potential of creative economy developed by millennials in Bengkulu City so that it can be included in the form of poverty reduction strategy in Bengkulu City. Data collection techniques in this study are: Observation, interview, FGD (FocusGroup Discussion) and Brain-storming. Data analysis was conducted simultaneously via on going analysis with data analysis technique for qualitative research.

The changes observed in this study are: (1) Investigating the role of millennials in the development of creative industries to alleviate poverty in Bengkulu City. (2) Develop poverty reduction strategy of Bengkulu City through the role of millennials in developing creative industries in Bengkulu City.

\section{RESULTS AND DISCUSSION}

Based on the results of surveys in the field it is known that today millennials dominate the creative business in Bengkulu city with an average of almost $80 \%$ of the 707 existing creative industries. The creators of this creative industry are average in the age of 20 to 40 years. A country will prosper if it has at least $2 \%$ entrepreneurs of the total population [11].

Success in developing creative industries is closely supported by the role of the entrepreneurs. According to the Central Statistics agency, the population of Bengkulu city aged 19-40 years reaches $55 \%$ of the population in Bengkulu city, this indirectly explains that Bengkulu city has demographic bonuses as measured from the age of the labor force. The age range that has great potential in running a business; indirectly leads to millennials a group born after 1980 to 2000 [12].

This group of millennials has additional ability to get information and create job opportunities but in running its business they must be followed by the ability to conduct business analysis [13]. In addition, creativity is needed to create innovations that are able to provide competitive value. Entrepreneurial readiness can be seen from skills and attributes in a variety of individual perspectives through the process of learning, practicing and developing behaviors.

However, millennials are known to have a spontaneous courage in deciding to start a business. They also have sensitivity to technological and information changes, especially in the intelligent and critical character of the business industry and the challenges in producing products/ services that correspond to the shifting tastes of a market that tends to be dynamic and fast [14]. In addition, this group is not easily affected by advertisements but is more likely based on experience information from family, friends and the environment. Based on the results of surveys $\backslash$ the role of millennials in developing creative industries in Bengkulu city can be seen as follow:

\section{Product}

The main part that millennials offer to develop creative industries is the products themselves. Products are everything that can be offered to the market for attention, purchase, use, or consumption that can satisfy desires or needs.

There are several attributes that accompany and complement products developed by millennials such as: (1) branding, almost $85 \%$ of the creative industries developed by millennials in Bengkulu city have their own brand or brand. Brands attached to their products become an attraction for consumers. With the brand, they are easier to market products resulting from creative industry development so as to be differentiating their products with other products. This generation is bolder to use their own brand and develop their brand image than to use other brands; (2) Packaging, this packaging process is differentiation characteristic of the creative industries developed by millennials with other UKMs. This is because millennial consumers in this industry prefer an attractive packaging so it is not uncommon for them to update it on their social media. According to information from the Cooperative and UKM Office of Bengkulu City (Mr. Dedi Susanto) one of the causes of UKMs in Bengkulu city is still left behind due to less attractive packing. Although the quality of the product is good but without a good packing,it will be difficult to accept by consumers, especially from millennials. But in contrast, the millennial products, it haspackaging that is able to compete in market share locally, regionally and nationally; and (3) Product Quality. Behavior in entrepreneurship is related to the product quality and the creative industry products in Bengkulu city produced by millennials are not inferior to other products. 
Millennials in Bengkulu who develop creative industries have a higher level of creativity and more innovative by paying attention to the attributes of the product. In developing, each product tends to capitalize on the momentum of global change and disruption or innovate that will replace the old system in a new way in developing every product they develop.

The creativity that emerges from these millennials arises from science, technology, innovation and technology. Products developed by millennials in Bengkulu City are presented more closely following the tastes of millennial consumers with good packaging and quality.

2. Price

Price is an attribute attached to an item that allows it to meet the needs, desires and satisfaction of consumers [16]. The price of any creative industry processed products from millennials is still classified as middle to lower prices. They are able to create quality products with high innovation at relatively flexible and competitive prices. This is because the raw materials of the products are from the areas around Bengkulu city.

3. Place

In running the business, millennial in Bengkulu city does not make the place as a major factor anymore. They more focus on quality business products so that it is not surprising when doing creative industry data collection in Bengkulu city many are located in the streets, alleys or housing.

\section{Promotion}

Based on the results of surveys in the field of promotional activities of millennials in Bengkulu City who develop creative industries is still heavily influenced by the world of digital and technology. In developing creative industries, this generation is the fastest learner and this age group has entrepreneurial potential and huge market potential. Thus, this millennial generation is the fastest generation to learn and adapt to almost any form of technological innovation. The development of technology that is happening now also provides opportunities for millennials, especially in Bengkulu City, to be able to develop or start a business based on digital technology. Millennial skills in social media are also a great potential in starting to be entrepreneur.

These millennials tend to be more open to the technological and information changes. Promotion by millennials in developing their creative industries through promotion on social media. These millennials usually take advantage of this type of promotion because through social media it has a wide reach geographically. In promoting their efforts, they tend to be influencers. This is what is causing their business to grow.

\section{Resources}

Millennial generations are the most potential resource in developing creative industries. The resource features of this group such as easily bored on the goods they buy; Usually, "no gadget no life" is a term attached to them; Comfortable of making non-cash payments; Love the fast paced and instant; Choose experience over assets; Different behaviors in one group and the other; Multitasking whiz; Critical of social phenomena; Likes to post and share on social media with its creativity and innovation has a greater opportunity to respond to the development of creative industries. The millennial is $55 \%$ of the population in Bengkulu City, this means that generations with the age of 19-40 years can be the economic driver of the Bengkulu City. The creative industries sector in Indonesia must be seriously developed with the aim of preparing the younger generation of Indonesians in the hope that they can become successful creative entrepreneurs and have a future impact on the Indonesian economy.

Based on the surveys, the development of millennials creative industries has the potential to grow and grow quickly. The existence of creative industries from millennials is necessary to increase economic growth in Bengkulu City because the real contribution of this sector is able to be a model to reduce poverty in Bengkulu city while improving welfare and reducing unemployment.

\subsection{Poverty reduction strategy of Bengkulu City through the role of millennials in developing creative industries}

The first Priority Program of the Bengkulu City Government is poverty alleviation and catching up with other cities. This is set out in the Regional Medium-Term Development Plan (RPJMD) 2019-2023. According to law No. 24 of 2019 about Creative Economy, government encouraging all aspects of creative economy in accordance with the development of culture, technology, creativity, innovation of Indonesian society, and the changing environment of the global economy; prosper the people of Indonesia and increase the country's income; create a creative economic ecosystem that is globally competitive; create new employment opportunities that side with the value of Indonesian art and culture as well as local economic resources; optimize the potential of Creative Economic Actors; protect the creativity of Creative Economic Actors; and prioritize creative economy in the National Development Plan.

In line with this, the countermeasure strategy is intended to increase the role of millennials in Bengkulu city to develop creative industries so as to reduce the unemployment rate and reduce poverty in Bengkulu City. Poverty alleviation through the role of millennials in developing creative industries has considerable potential, this strategy will lead to more socio entrepreneurs, pursuing poverty alleviation goals with entrepreneurial spirit, business methods and courage to innovate. 
Questionnaires are used to obtain data from respondents. The design of the questionnaire consists of indicators of internal and external environment. The interviews results consisted of 85 potential samples with solving techniques.

The design of the questionnaire consists of external and internal environmental data presented in Table 1:

Table 1 Internal and External Environment Indicators

\begin{tabular}{|c|c|}
\hline Internal Factors & External Factors \\
\hline $\begin{array}{l}\text { Strength indicators: } \\
\text { - Organization } \\
\text { - } \text { Resource } \\
\text { - } \text { Management } \\
\text { - } \text { Product Development } \\
\text { - } \quad \text { Product diversity }\end{array}$ & \begin{tabular}{l}
\multicolumn{2}{l}{ Opportunity indicators : } \\
- $\quad$ Lifestyle \\
- $\quad$ Technology \\
- $\quad$ Consumer income \\
- $\quad$ Cooperation \\
- $\quad$ Government policy
\end{tabular} \\
\hline $\begin{array}{l}\text { Weakness Indicators: } \\
\text { - Experience } \\
\text { - Financial } \\
\text { - Capital } \\
\text { - Consistency } \\
\text { - Age }\end{array}$ & $\begin{array}{l}\text { Threat Indicators: } \\
\text { - } \quad \text { Economic } \\
\text { - } \quad \text { No Event } \\
\text { - } \quad \text { Political } \\
\text { - } \quad \text { Competitors } \\
\text { - } \quad \text { Free market. }\end{array}$ \\
\hline
\end{tabular}

The systematic of scoring presented in Tables 2-5 is carried out with the following provisions:

1. Fixed weighting uses a scale of 1 (very unimportant) to 4 (very important), but the determination of the scale value for each total situation is 1 , by sorting the situation factors by priority scale (SP) (the highest value is 16 out of $4 \times 4$, the order of 2 values is $3 \times 4=12$ and the lowest value is 4 out of $1 \times 4$ ) and then multiplied by constant $(\mathrm{K})$ the highest value is 4
2. Scale values are determined based on the priority of each situation (e.g. scale 4 for the most important opportunity)

3. Highest value obtained from weight result $x$ Rating

Based on the results of the internal factor analysis of the above strength indicators, it can be known the results of the score. In Table 2, the strength factor (S) has a score of 3.5. Considerable potential is found in organizational indicators (the organization's ability to grow businesses) and resource management indicators (ability to manage business management) with a score of 1.2.

Based on the results of the internal factor analysis of the weakness indicators, it can be known the results of the score. In Table 3, the weakness factor (W) has a score of 2.8. Considerable potential is found in capital indicators (Limited venture capital) with a score of 0.9 and indicators of consistency (Less consistent and easily bored) with a score of 1.2 .

Based on the results of the external factor analysis of the odds indicator above, it can be known the results of the score. In Table 4 above the odds factor $(\mathrm{O})$ has a score of 3.1. Considerable potential is found in cooperation indicators (cooperation between partners to facilitate production to marketing) with a score of 1.2 and government policy indicators (government policies that facilitate the development of creative industries) with a score of 0.9 .

Based on the results of the analysis of external factors of the above threat indicators, it can be known the results of the score. In Table 5, the threat factor $(\mathrm{T})$ has a score of 3.4. Considerable potential is found in the indicator of no Event (no Event caused by the health issue of "coronavirus") with a score of 0.9 and free market indicators (open market making it easier to process transactions either online or offline) with a score of 0.9 .

Table 2 Total internal factor score strength indicator (X1)

\begin{tabular}{|c|c|c|c|c|c|}
\hline \multicolumn{2}{|l|}{ Indicators } & Statement & $\begin{array}{c}\text { Value } \\
\text { Weights } \\
(\mathrm{NB})\end{array}$ & $\begin{array}{c}\text { Value } \\
\text { Rating } \\
(\mathrm{NR}) \\
\end{array}$ & \multirow{2}{*}{$\begin{array}{c}\text { Score } \\
\text { NB x } \\
\text { NR) } \\
1,2^{*}\end{array}$} \\
\hline Organization & $\mathrm{X} 1$ & The organization's ability to grow & 0.3 & 4 & \\
\hline $\begin{array}{l}\text { Resource } \\
\text { Management }\end{array}$ & $\mathrm{X} 2$ & Ability to manage business management & 0.3 & 4 & $1.2^{*}$ \\
\hline $\begin{array}{l}\text { Product } \\
\text { Development }\end{array}$ & $\mathrm{X} 3$ & $\begin{array}{l}\text { The emergence of the spirit to develop } \\
\text { product }\end{array}$ & 0.2 & 3 & 0.6 \\
\hline Creativity & $\mathrm{X} 4$ & Product has high creativity value & 0.1 & 2 & 0.2 \\
\hline Product diversity & $\mathrm{X} 5$ & $\begin{array}{l}\text { The diversity of quality products offered in } \\
\text { the market }\end{array}$ & 0.1 & 3 & 0.3 \\
\hline & & Amount & 1.00 & & 3.5 \\
\hline
\end{tabular}


Table 3 Total scores of internal factors weakness indicator (X2)

\begin{tabular}{|c|c|c|c|c|c|}
\hline Indicators & & Statement & $\begin{array}{c}\text { Value } \\
\text { Weight } \\
\text { s } \\
(\mathrm{NB}) \\
\end{array}$ & $\begin{array}{c}\text { Value } \\
\text { Rating } \\
(\mathrm{NR})\end{array}$ & $\begin{array}{c}\text { Score } \\
\text { NB x } \\
\text { NR) }\end{array}$ \\
\hline Experience & X6 & Lack of experience running a business & 0.1 & 2 & 0.2 \\
\hline Financial & $\mathrm{X} 7$ & Unstable financial condition & 0.1 & 3 & 0.3 \\
\hline Capital & $\mathrm{X} 8$ & Limitations of venture capital & 0.3 & 3 & $0.9^{*}$ \\
\hline Consistency & X9 & Less consistent and easily bored & 0.4 & 4 & $1.2 *$ \\
\hline \multirow[t]{2}{*}{ Age } & $\mathrm{X} 10$ & $\begin{array}{l}\text { The age of creative industries can be long } \\
\text { lasting }\end{array}$ & 0.1 & 2 & 0.2 \\
\hline & & Amount & 1.00 & & 2.8 \\
\hline
\end{tabular}

Table 4 Total external factor scores of opportunity indicators (X3)

\begin{tabular}{|c|c|c|c|c|c|}
\hline Indicators & & Statement & $\begin{array}{c}\text { Value } \\
\text { Weights } \\
\text { (NB) }\end{array}$ & $\begin{array}{c}\text { Value } \\
\text { Rating } \\
(\mathrm{NR})\end{array}$ & $\begin{array}{l}\text { Score } \\
\text { NB x } \\
\text { NR) }\end{array}$ \\
\hline Lifestyle & $\mathrm{X} 11$ & $\begin{array}{l}\text { Millennial instant lifestyle that likes to } \\
\text { update in social media }\end{array}$ & 0.1 & 2 & 0.2 \\
\hline Technology & $\mathrm{X} 12$ & $\begin{array}{l}\text { Technological advances that facilitate } \\
\text { activities }\end{array}$ & 0.1 & 2 & 0.2 \\
\hline Consumer income & $\mathrm{X} 13$ & $\begin{array}{l}\text { High purchasing strengthof the } \\
\text { community }\end{array}$ & 0.2 & 3 & 0.6 \\
\hline Cooperation & $\mathrm{X} 14$ & $\begin{array}{l}\text { Cooperation between partners makes it } \\
\text { easier in production to marketing } \\
\text { processes }\end{array}$ & 0.3 & 4 & $1.2^{*}$ \\
\hline \multirow[t]{2}{*}{ Government policy } & $\mathrm{X} 15$ & $\begin{array}{l}\text { Government policies that facilitate the } \\
\text { development of creative industries }\end{array}$ & 0.3 & 3 & $0.9 *$ \\
\hline & & Amount & 1.00 & & 3.1 \\
\hline
\end{tabular}

Table 5 Total external factor scores of threat indicators (X4)

\begin{tabular}{|c|c|c|c|c|c|}
\hline Indicators & & Statement & $\begin{array}{c}\text { Value } \\
\text { Weights } \\
\text { (NB) }\end{array}$ & $\begin{array}{l}\text { Value } \\
\text { Rating } \\
(\mathrm{NR})\end{array}$ & $\begin{array}{l}\text { Score } \\
\text { NB x } \\
\text { NR) }\end{array}$ \\
\hline Economic & $\mathrm{X} 16$ & $\begin{array}{l}\text { There is a high inflation rate in Bengkulu } \\
\text { City }\end{array}$ & 0.2 & 3 & 0.6 \\
\hline No Event & $\mathrm{X} 17$ & $\begin{array}{l}\text { No event available because of the } \\
\text { "corona virus" health issue }\end{array}$ & 0.3 & 3 & $0.9 *$ \\
\hline Political & $\mathrm{X} 18$ & $\begin{array}{l}\text { The change of regional head caused a } \\
\text { change in government policy in order to } \\
\text { protect the creative industries }\end{array}$ & 0.2 & 2 & 0.4 \\
\hline Competitors & X19 & $\begin{array}{l}\text { The emergence of similar product } \\
\text { competitors at competitive prices }\end{array}$ & 0.2 & 3 & 0.6 \\
\hline \multirow[t]{2}{*}{ Free market. } & $\mathrm{X} 20$ & $\begin{array}{l}\text { Open Market making it easier to process } \\
\text { transactions either online or offline }\end{array}$ & 0.3 & 3 & $0.9 *$ \\
\hline & & Amount & 1.00 & & 3.4 \\
\hline
\end{tabular}


Table 6 Total Internal and External Factor Values

\begin{tabular}{lllll}
\hline \multicolumn{2}{c}{ Internal Factor Value } & & & External Factor Value \\
\hline Strength & 3.5 & Opportunities & 3.1 \\
Weakness & 2.8 & Threat & 3.4 \\
Total & 6.0 & Total & 6.9 \\
\hline
\end{tabular}

\subsection{SWOT Analysis Diagram}

Table 6 shows that there is a combination of matric strategies that can be found from the merging indicators of internal and external factors. On internal and external factors, the highest value is derived from the strength factor (3.5) and the threat factor (3.4). From these results it can be concluded that although the external factor value of the threat has a high value, it can be overcome by internal factors of strength that have a higher value.

Figure 1 shows that the strategy that supports millennials in developing creative industries in Bengkulu is a diversification strategy. In this strategy, despite many threats, the company still has internal strengths. Therefore, the strategy must be implemented by using the strength to utilize long-term opportunities by diversifying (products/ services).

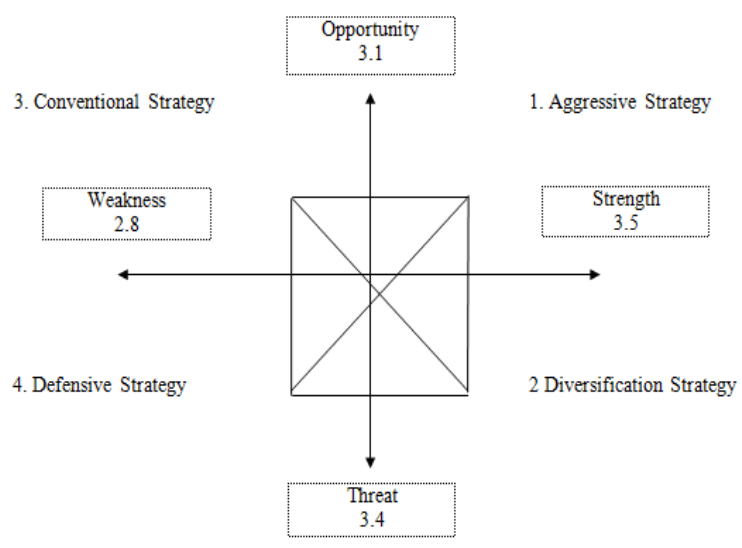

Figure 1 SWOT Quadrant

Based on SWOT calculations, the poverty reduction strategy is presented through the role of millennials in developing creative industries in Bengkulu city presented in Table 7.

Based on the results of research it is known that the creative industry developed by millennials in Bengkulu city has good potential to be developed as an input for Bengkulu city government for a poverty reduction solution in Bengkulu City. The possible strategies are as follows:

1. Optimize the organization's ability to grow creative industry businesses and optimizing management capabilities to manage creative industry. This activity is conducted in a way that millennials get technical guidance training, mentoring, and human resources development. Technical guidance, mentoring, and human resource development need to be done to address issues related to business management, production techniques, offline and online marketing, product standardization, intellectual property management and financial management training. This creative industry has a high absorption of labor with a level of work skills that can easily be mastered. Therefore, if all creative industries are properly improved, it has high contribution in creating jobs and lowering the poverty rate in Bengkulu City.

2. Expand the networking to facilitate the production and marketing processes of creative industries and multiply policies that encourage the development of creative industries from millennials. This is achieved by: expanding the network of raw material suppliers to marketing networks both on a national and international scale. Cooperation with influencers, various marketing applications so the marketing reaches not only local but also national even international. The government as the driving regulator of various policies creates various activity programs focused on the development of creative industries in Bengkulu city and encouraged the creation of a superior creative industry from Bengkulu city that has intellectual property rights, quality, representative of Bengkulu city which able to penetrate the international market.

3. Optimization of venture capital and optimizing consistency in running the business. This is done by encouraging and providing training for millennials on how to manage venture capital, ranging from careful planning, focusing on business, monitoring business finance, making good cash flow books and encouraging the growing of tenacious attitude in developing business.

4. Arrange events in the New Normal era and preparing 
efforts to face the free market. Creative Industries cannot be separated from the tourism sector. The event was reduced due to the covid-19 pandemic causing the sector to fall. Creative industry developers should be required to survive by preparing events in the new era either online or offline event. Improving the quality of products. Creative and innovative businesses are always sensitive to changing market tastes so improvement is important to be able to compete in the free market and export market.
5. Conducive business climate

Investment is urgently needed for a good business. The better the business climate in Bengkulu, the faster the investment activity in Bengkulu. This conducive climate should be supported by the development of infrastructure, communication, information and various creative talents. Various creative economic sectors also need to persuade in bringingthe innovation that echoes to the international level so that it will become alive and synergistic, as well as become a magnet for investors and companies in Bengkulu City.

Table 7 Swot Matric Poverty Reduction Strategy through the role of millennials in developing creative industries in Bengkulu City

\begin{tabular}{|c|c|c|}
\hline IFAS & \begin{tabular}{l}
\multicolumn{1}{c}{ STRENGTHS(S) } \\
Organization, Resource \\
Management, Product \\
Development, Creativity, Product \\
diversity
\end{tabular} & $\begin{array}{l}\text { WEAKNESSES }(\mathbf{W}) \\
\text { Experience, Finance, Capital, } \\
\text { Consistency, Age }\end{array}$ \\
\hline $\begin{array}{l}\quad \text { OPPORTUNITIES (O) } \\
\text { Lifestyle, Technology, Consumer } \\
\text { income, Cooperation, Government } \\
\text { policy }\end{array}$ & $\begin{array}{l}\text { (SO) STRATEGY } \\
\text { 1. Optimizing the organization's } \\
\text { ability to grow creative industry } \\
\text { 2. Optimize management } \\
\text { capabilities to manage creative } \\
\text { industry } \\
\text { 3. Expand the partnership network } \\
\text { to facilitate the production and } \\
\text { marketing process of the } \\
\text { creative industries } \\
\text { 4. Multiply policies that encourage } \\
\text { the development of creative } \\
\text { industries from millennials }\end{array}$ & $\begin{array}{l}\text { (SW) STRATEGY } \\
\text { 1. Business capital optimization } \\
\text { 2. Optimize consistency in running } \\
\text { your business } \\
\text { 3. Expand the partnership network } \\
\text { to facilitate the production and } \\
\text { marketing processes of the } \\
\text { creative industries } \\
\text { 4. Multiply policies that encourage } \\
\text { the development of creative } \\
\text { industries from millennials }\end{array}$ \\
\hline $\begin{array}{l}\text { TREATHS (T) } \\
\text { Economics, Events, Politics, } \\
\text { Competitors, Free markets. }\end{array}$ & $\begin{array}{l}\text { (ST) STRATEGY } \\
\text { 1. Optimizing the organization's } \\
\text { ability to develop creative } \\
\text { industry } \\
\text { 2. Optimize management } \\
\text { capabilities to manage creative } \\
\text { industry efforts } \\
\text { 3. Arrange events in the new } \\
\text { normal era } \\
\text { 4. Preparing the businesses for the } \\
\text { free market }\end{array}$ & $\begin{array}{l}\text { WT STRATEGY } \\
\text { 1. Business capital optimization } \\
\text { 2. Optimize consistency in running } \\
\text { businesses } \\
\text { 5. Arrange events in the New } \\
\text { Normal era } \\
\text { 6. Preparing the businesses for the } \\
\text { free market }\end{array}$ \\
\hline
\end{tabular}

\section{CONCLUSION}

The results of the study show that almost $80 \%$ of the creative industries in Bengkulu city are developed by millennials. The results of this study also show that the role of millennials in developing creative industries such as product development, price, place, promotion and resources has the potential to rapidly grow and develop as a poverty reduction effort in Bengkulu City. The strategy that supports millennials in developing creative industries in Bengkulu city is a diversification strategy. In this strategy despite many threats, the company still has the strength to take advantage of long-term opportunities by diversifying (products/services). The strategies structured are as follows: (1) Optimizing the organization's ability to develop creative businesses and optimizing management's ability to manage creative industry efforts. (2) Increase the partnership network to facilitate the production and marketing process of creative industries and multiply policies that encourage the development of creative industries from millennials. (3) Optimization of venture capital and optimizing consistency in running the 
business. (4) Arrange events in the new normal era and prepare the businesses to face the free market. Creative Industries cannot be separated from the tourism sector. (5) Maintain the conducive business climate

\section{ACKNOWLEDGMENT}

Authors thanks to KEMENRISTEKDIKTI-BRIN for the financial support to through Project No. 182/ SP2H/LT/DRPM/2020 (Penelitian Dosen Pemula).

\section{REFERENCES}

[1] B. Bidani, M. Ravallion, A regional poverty profile for Indonesia. Bulletin of Indonesian Economic Studies, 29 (3) (1993), 37-68. DOI: https://doi.org/10. $1080 / 00074919312331336451$

[2] E. M. Siburian, M. F. Rahmadana, Analysis Factor Influence Poverty on Bengkulu. Proceeding of the 2nd Annual International Seminar on Transformative Education and Educational Leadership, 2017. DOI: https://doi.org/10.2991/aisteel-17.2017.76

[3]S. Aryati, G. Salsabila, M. H. Thilfatantil, A. Christianawati, F. R. Prima, Poverty In Bengkulu Province 2010-2017. Jurnal Geografi: Media Informasi Pengembangan dan Profesi Kegeografian, 16 (2) (2019) 137-144. DOI: https://doi.org/10.15294/jg.v16i2.20857

[4] S. Sudjatmiko, C. Mohammad, M. Zainal, S. Nanik, Closed Farming System: An Alternative Poverty Eradication in Kabupaten Rejang Lebong, Bengkulu Province, Indonesia. The $4^{\text {th }}$ International seminar of Regional Network on Poverty Eradication, 2013.

[5] M. G. Irham, L. R. Waluyati, A. Suryantini, The importance of combining various methods in assessing poverty level: The case of marine capture fishermen in Bengkulu Province, Indonesia. Journal of International Studies, 12(2) (2019) 241-257. DOI: https://doi.org/ $10.14254 / 2071-8330.2019 / 12-2 / 15$

[6] A. Soleh, K. Sukiyono, R. Nurazi. Inclusive Growth in Bengkulu Province: Multidimensional Approach. In First International Conference on Progressive Civil Society, 2019. DOI: https://doi.org/10.2991/iconprocs19.2019 .18

[7] A. Muktadir, D. D. Perdana, M. Irmayanti, Communication, Language Acquisition and Development Of Visit Bengkulu 2020. In International Conference Primary Education Research Pivotal Literature and Research UNNES, 2018. DOI: https://doi.org/10.2991/icpeopleunnes-18.2019.17

[8] S. Nasution, T. Irwanto, Public perception of the potential of waterfall tourism in bengkulu province after the enactment of the new normal covid pandemic 19. Jelajah: Journal of Tourism and Hospitality, 2 (1) (2020) 22-32. DOI: https://doi.org/10.33830/jelajah. v2i1.891

[9] M. Susanti, K. Karim, M. Herfianti, E. P. M. Damarsiwi, E. A. Ahmadi, Utilization of Palm oil Plant as a Creative Business in Supporting the Economy: Making Food Plate. International Journal of Psychosocial Rehabilitation, 24 (2) (2020) 1388-1394. DOI: https://doi.org/10.37200/IJPR/V24I2/PR200438

[10] R. N. Suwarni, M. Fahlevi, M. N. Abdi, Startup Valuation by Venture Capitalists: An Empirical Study Indonesia Firms. International Journal of Control and Automation, 13 (2) (2020) 785-796.

[11] I. Z. Rohman, M. Miswanto, The Influence of Personality Factors on Entrepreneurial Intention. Jurnal Manajemen Bisnis, 11(2) (2020) 23-31.

[12] W. Parimita, D. Purwana, U. Suhud. Gender perspectives in individual and organizational factors: A study of millennial employees in creative industries. Management Science Letters, 11 (1) (2020) 11-20. DOI: https://doi.org/10.5267/j.msl.2020.8.035

[13] G. A. García, D. R. Gonzales-Miranda, O. Gallo, J. P. Roman-Calderon. Employee involvement and job satisfaction: a tale of the millennial generation. Employee Relations: The International Journal 2 (2) (2019) 1-18.

[14] C. M. Graham, H. Daniel, B. Doore, Millennial Teamwork and Technical Proficiency's Impact on Virtual Team Effectiveness: Implications for Business Educators and Leaders. International Journal of eCollaboration, $12 \quad$ (3) (2016) 34-50. DOI: https://doi.org/10.4018/IJeC.2016070103

[15] P. Kotler, G. Armstrong, S. H. Ang, S. Leong, C. T. Tan, O. Ho-Ming, Principles of marketing: an Asian perspective. New York: Pearson/Prentice-Hall, 2012.

[16] P. Benigno, Price stability with imperfect financial integration. Journal of Money, credit and Banking, 41 (2009) 121-149.https://doi.org/10.1111/j.1538-4616. 2008.00201.x 